\title{
ICT and Education for Refugees in Transit
}

Dewi Sari Wahyuni ${ }^{1} \&$ T. Sy. Eiva Fatdha ${ }^{2}$

${ }^{1}$ STMIK Amik Riau

\begin{tabular}{|c|c|}
\hline ARTICLE INFO & ABSTRACT \\
\hline Article history: & \multirow{13}{*}{$\begin{array}{l}\text { Refugees in transit often have no access to formal education. } \\
\text { Indonesia as one of transit countries has allowed these community } \\
\text { school-age children to join public school. Unfortunately, teenagers } \\
\text { and adults do not have similar consent. As most of them are stranded } \\
\text { for a long time to skip their basic education, there should be a bridge } \\
\text { so that they still can catch up with their secondary or even higher } \\
\text { education level. During their uncertain waiting time, some } \\
\text { international and national organizations and local institutions have } \\
\text { provided them with private classes in specific subjects. The problem } \\
\text { is these classes are unaligned with the lesson grade in host country } \\
\text { formal education institution, which is categorized based on learners' } \\
\text { ages. Moreover, they are placed in separated places (detention centre, } \\
\text { interception, community housings) which cost time and fare to get } \\
\text { these refugees in one education centre. The alternative solution for } \\
\text { handling this situation is by having blended learning, a combination } \\
\text { of online learning platform and face-to-face meeting managed by } \\
\text { teachers both from the host country and refugees. These students } \\
\text { although they are limited by any means, have been familiar with ICT } \\
\text { such as Microsoft Office, Photoshop, Multimedia and Internet. The } \\
\text { online learning platform will muddle through time and distance in } \\
\text { order to support them to take Package A, B, C (National Elementary, } \\
\text { Junior and Senior High School Equivalency) tests as these tests are } \\
\text { admitted at work and further study in host country as well as their } \\
\text { destination countries without age limitation }\end{array}$} \\
\hline Received April 26, 2019 & \\
\hline Revised May 25, 2019 & \\
\hline Accepted June 20, 2019 & \\
\hline Keywords: & \\
\hline $\mathrm{ICT}$ & \\
\hline Education, & \\
\hline Refugees, & \\
\hline Transit & \\
\hline Clonflict of Interest: & \\
\hline None & \\
\hline Funding: & \\
\hline None & \\
\hline
\end{tabular}

Corresponding Author: Dewi Sari Wahyuni, STMIK Amik Riau, J1. Purwodadi Indah KM. 10, Panam, Pekanbaru, Riau, Indonesia. Email: dewisariwahyuni@gmail.com

\section{Introduction}

Both of refugee and asylum seekers are the ones who have been forced to flee their home country because of persecution, war or violence. Whether the reasons are race, religion, nationality, political opinion or membership in a particular social group, they are all scared of persecution. In all likelihood, it is almost impossible for them to go back home. The main causes of this fear are war and ethnic, tribal and religious violence. The differentiation from refugees and asylum seekers status by United Nations High Commissioner for Refugees (UNHCR) is merely based on the process of their registration under UNHCR protection. An asylum-seeker is someone who is seeking international protection whose request for protection is under processing. Not every asylum seeker will eventually be given status as a refugee, but every refugee is once was an asylum seeker. Both of them will be referred to as refugees in this article. 
Statistics revealed that in 2016, 91 percent of children all over the word joined primary or elementary school. However, there were only 61 percent of the children refugees and asylum seekers had access to this basic education although it rose from 50\% in $2015.84 \%$ children the world continued their education but children refugees and asylum seekers had only 23 percent of them to join secondary school.

In 2017, more than half of the total number of children refugees in the world barely went to school. In 2018, 3.5 million from the total number of 6.4 million of them from age 5-17 did not have access to education. The number was reduced from 3.7 million in 2015. Meanwhile, 17.2 million refugees under UNHCR's protection were children. Education for these children in their marginal community is crucial for peace and sustainability of their destination country. Education for them is the future for the welfare of the countries that accommodate these refugees.

Based on United Nations High Commissioner for Refugees (UNHCR) Indonesia factsheet, a total number of refugees and asylum seekers as of February 2016 were 13,829 with their country of origin are Afghanistan, Myanmar, Somalia, Sri Lanka, Iran, Palestine, Pakistan, Iraq and others. More and more asylum seekers have stranded in Indonesia that at the end of 2018, it was predicted that there were about 14,000 of them. A fourth of those numbers were children that did not have chance to have formal education. Meanwhile, in the world fifty percent of the said children missed their formal education.

\section{Refugees in Transit}

In Pekanbaru, there were 1.149 refugees and asylum seekers by the end of 2018. Their basic needs were provided by International Organization for Migration (IOM) by coordinating with Immigration and local government officers. These refugees were provided with three kinds of shelters; Detention Centre, Interception and Community Housing.

Detention Centre was previously intended for asylum seekers, be them single or family. As more and more asylum seekers were in Pekanbaru, it was no longer fit the number of people that could be accommodated. Then, this shelter was available only for the men and single both without distinguishing whether they were refugee or asylum seeker. Single in this context means that the particular person was practically alone in Pekanbaru. Some of them had wife and children back then in their home country or in other country. Apart from the reasons why they were separated from their family they were considered as 'single' and placed together with the 'real single' that was the one who has not yet got married and had children. It was planned that in 2019, there will be no more refugees and asylum seekers stay in this place.

The second one was called Interception. The said accommodation was for both refugees and asylum seekers. Single and family were placed in different area and it prevailed the same with the unaccompanied minors, children/ under eighteen without adult's companion. This place was originally for both refugees and asylum seekers who were single. For Detention Centre could no longer accommodate the new comer who kept on coming, some of single asylum seekers who were supposed to be kept in Detention Center whom were considered behaved were moved to these Interception to stay together with refugees.

The last is Community Housings. This shelter is meant for refugees who were waiting to be resettled to the third/destination countries. Most of these shelter inhabitants were family and even though a few of them were single, they had relatives at the same community housings. Since the new trend of rejection from their destination country, those refugees are going to be in Indonesia for indefinite time.

\section{Refugees and Education in Transit}


School age children in Pekanbaru are divided into two categories. They are 7-12 years old and 13-18 years old. Less than ten children from the first group had already joined private elementary school with their own parents' expenses. International organization such as UNHCR and International Organization (IOM) had arranged it with the local government to make public elementary school available for these specific children to go in 2019. The problem occurred to the second age group. Some of them had been staying in Pekanbaru since five of six years ago. They had missed their basic education as they got here the chance was not yet possible for them for having formal education.

Eleven percent of this 7-12 years old group definitely will get the chance to have their formal education, while 7\% of 13-18 years old need some times and processes to be able to attend public school. Meanwhile, they will run out of time and they are getting older during their indefinite waiting time.

There were home schoolings provided by IOM with its Indonesian service providers. Specific subjects were taught by appointed local institutions to run the education for children. As these children grew up to be teenagers, the classes were divided into nursery, children and teenagers. They were taught specific subjects in English and in Indonesia. Before the local institutions were available to serve, several On Call teachers worked under IOM were hired to teach them English and Indonesia which was initially intended for all; children, teenagers, adults. Previously, the processes on going to the third countries were not so complicated as per nowadays. There were not many children for most of the refugees were 'single'. Then, as more and more family came, the basic education was unavoidable. On Call Teachers started to work hand in hand with the teachers from local institutions to keep the education going for these children.

Some of refugees themselves also set up classes on their behalf, previously by setting them to their own people from similar country of origin. Since they were from different countries, and there were not many refugees in Pekanbaru back then, it was still possible to place them in different area or shelter based on their home country. It was also intended to avoid any chaos and disputes that often occurred when they were mixed. The shelter with less multiculturalism refugees tended to be more peaceful than the mixed ones.

However, the wave of refugees kept on coming in Indonesia and Pekanbaru as one of the temporary settlements for them was also influenced. Placing them based on their home country was no longer conceivable, so they had to be settled into multicultural shelter, which were divided into 'single' and 'family'. These refugees, as they started to adapt, also set classes with multilingual students from various home countries. They learned how to be more adjustable and being more tolerant that latter will help them to integrate with the local people.

\section{Type of Education}

The education for children refugees in Pekanbaru was divided into three types; formal education, non-formal education, informal education. Less than $1 \%$ of children have joined private Indonesian elementary school with their parents' expenses. Actually, the school fee was not expensive that some of the refugees still could afford them. However, there were not many parents sent their children to school. For non-formal education, IOM provided it with its service providers, private local institutions and on call teachers. It also empowered refugees themselves to set up scheduled and organized classes. Beyond what IOM set up, there were also classes managed by refugees outside the provided classroom.

\section{Education Challenge}




\subsection{Authorities Rules and Regulation}

Indonesia is not a state party to 1951 Refugee Convention and its optional protocol but it complies with other international human rights treaties. Therefore, the government had no obligation to provide other than basic education as part of the human rights. Secondary education will be a long further discussion.

Even for basic education, the rules and regulation for attending public school was still far beyond what refugees could access. They could not cope with the very basic requirements such as Family Identity Card and Birth Certificate as they fled from their country and entered Indonesia illegally. For children of primary school age, it is still endeavored that they might join the public school. These children had been prepared with Indonesian class and some of the basic subject that they might learn at formal school. The preparation is to develop themselves and in 2019, they will be assisted and given access to attend public school.

\subsection{Local Societies' rejection on inclusion}

Many projects had provided by UNHCR and IOM to the inclusion of these refugees with the local people. They were joining sport competitions, cleaning the environment, gardening and other activities that make them mingle with the society. Nevertheless, some local people were still unable to let themselves blend with these refugees. Things considered small stuffs for refugees turned out to be a problematic issue to the local people and the other way around.

Many refugees came from several countries and adhered to different religious sect than the majority oo the local people. Due to this, most locals do not want them to be around. Moreover, some negative attitudes done by the small number refugees were also sensitive issues that was going on within the local society that was appointed to all of the refugees that they were ungrateful for being welcomed and had been given permission to stay by creating negative impact to the society.

\subsection{Refugees' reluctance on integration}

Refugees various background; home countries and cultural practices added to the exclusion and specific group connection with tendency of being unsettled when they were obligated to mix with themselves not to mention with the local people. Even though most of these refugees have experienced in moving around from one country into another, their marginal life was not a much of help to their socialization with people outside of their community.

Developing intercultural awareness which concerns on understanding the others' culture and intercultural competence which is to manage relations with others will help them to understand and to apply responsibility, tolerance and inclusion (Etsuko Toyoda, 2016).

\subsection{Learning Center}

Every community had at least one classroom. This facility was inadequate considering the number of students and the classes that they needed. Instead of scheduling the class per their needs, they must fit the classes with the time availability for the vacant of the class, otherwise, the classes would be overlapped. In addition, the classes were so hectic and it was occupied for a long time, even from morning until night. The cleanliness of the class was hardly to be settled for there was not enough time for cleaning.

Even though a learning center especially for youth had been settled in one community housing, it was not really effective since the distance of each accommodation is more than $10 \mathrm{~km}$. Each accommodation was placed far from public transportation station while these refugees were not allowed to have their riding/driving license nor to own their own vehicles. It would also unaffordable for them to ride on taxis and other private ridings. 
Other thing that put this learning center ineffective was some parents mind that their young daughters to learn in there as the center was located in a 'single' community housing that inhibited by men. They doubted on their children safety and negative influence from the men that a few of them trigger some issues with the local people.

\section{Alternative Solutions}

\subsection{Refugees and ICT}

Refugees in Europe take advantage of ICTs for helping them communicate with their families and friends back home. It means that refugees mainly have good access and command of ICTs for the sake of social communication (Collin, S. \& Karsenti, T., 2012). They do not use them for further purposes such as accessing information about available education or even manage them as a means of learning media (Carretero \& Cente, 2015).

The majorities of refugees in Pekanbaru are familiar with ICT. At least a family has one or more smartphone(s). 50\% have more than a gadget. Families with children have laptops, and more than one smartphone(s) and or tablet(s).

Teenagers and adults also joined outside basic computer classes provided IOM with its service provider. They were introduced to Microsoft Office and Internet. A few of adult refugees claimed that they got bachelor degree and even master degree in their home country and had started to teach their fellows about computer and network. Some of them also joined online university in IT fields.

\subsection{Blended Learning}

World Bank (2016) stated that ICT can replace teachers and organized learning only in rare instances; but it can provide effective support to education, especially when supplemented with teacher training. Many seek evidence that technology-assisted approaches are effective, but little has been gathered with respect to ICT in education generally, let alone in emergency situations.

Although these group of refugees and refugees limited by any means, have been familiar with ICT such as Microsoft Office, Photoshop, Multimedia and Internet. Each of them has at least a laptop and/or a smartphone, either they use it by themselves or share it with their siblings.

Migrant and Refugees in transit often have limited access to formal education. Indonesia as one of transit countries has allowed these community school-age children to join nearby public school in some area and it was also limited to Primary School. Teenagers and young adults who have been stranded for years had to skip their formal education. Therefore, there should be a bridge for catching up with their Secondary or Higher Education level. During their uncertain waiting time, IOM has provided them with non formal education served by institutions, on call teachers, voluntary teachers in specific subjects. This is to support them to take Package A, B, C (National Elementary, Junior and Senior High School Equivalency) tests as these tests are admitted at work and further study in host country as well as their destination countries without age limitation.

The problem is these classes are unaligned with the lesson grade in host country formal education institutions, which is categorized based on learners' ages. Different institutions, on call teachers, voluntary teachers shared different lesson eventhough the subjects are similar and the students at the same age. The uniformity of curriculum is indeed needed and a learning centre has to be established. Unfortunately, they are placed in separated places (detention centre, interception, community housings) which cost time and fare to get 
them in one learning centre since opening it in each places will not be effective as the number of students unevenly spreaded for each places.

The teachers and students in the learning center should be trained in having knowledge and skills for using any appropriate learning management system application to manifest better and effective teaching and learning process in order to accomodate education sustanaibility on young refugees. It also will bridge digital immigrant voluntary teachers with their digital native students in their process of conveying the lesson. It acts as an alternative to limited time, space and expenses owned by refugees and refugees. In addition, the content delivered by using ICTs had to be approachable and adjustable to students' capability and in proportion to host country curriculum (Tauson \& Stannard, 2018).

Rodrigues (2018) indicated that refugees' achievement levels in their destination country could be improved by a more intense use of ICT at home for schoolwork and for general purposes. The evidence indicates that refugee students may be overusing ICT at school for educational purposes and also suggested that at school they may be in need of face-to-face support.

The alternative immediate solutions for handling this situation are both by having online learning platform and face to face meeting. Most of these people have already had internet connection and computers. Although they are limited by any means, they are familiar with ICT such as Microsoft Office, Photoshop and Multimedia. The online learning platform will muddle through time and distance. In spite of this using merely ICTs in schools or at home is inadequate to result in great learning outcomes (Joynes, C. \& James, Z., 2018)

Blended learning approach by having Learning Centre and e-learning focusing on mentoring and monitoring as a bridging for them to get formal education later on in the future whether they are going to depart to destination country or repatriate to their home country so that the education gab they had during their waiting time will be better bridged.

In case the path to be part of having formal education is a dead end, the following will be an alternative; (1) establishing specific learning centre that refer to formal education in Indonesia, (2) making use of online learning platforrm to handle limited time, space and expenses, (3) cooperate with licensed institutions which hold package A, B and C tets (National Elementary, Junior and High School Equivalency), (4) paving the way to university entrance in Indonesia and in their destination country.

\section{References}

Collin, S. \& Karsenti, T. (2012). ICT and Migration: A Conceptual Framework of ICT Use by Migrants. In T. Amiel \& B. Wilson (Eds.), Proceedings of EdMedia 2012-World Conference on Educational Media and Technology (pp. 1492-1497). Denver, Colorado, USA: Association for the Advancement of Computing in Education $\begin{array}{llll}\text { (AACE). Retrieved } & \text { February } & 2019\end{array}$ from https://www.learntechlib.org/primary/p/40945/.

Eds.: Carretero \& Centeno, Clara. (2015). ICT for the Employability and Integration of Immigrants in the European Union

Dosono, B. (2014). Digital Inclusion for Migrant Millennials: Improving the ICT Landscape of Yakima Valley Schools. In iConference 2014 Proceedings (p. 65-75). doi: $10.9776 / 14043$

Joynes, C. \& James, Z. (2018). An overview of ICT for education of refugees and IDPs. K4D Helpdesk Report. Brighton, UK: Institute of Development Studies 
Rodrigues, Margarida. (2018) Can digital technologies help reduce the immigrant-native educational achievement gap?, EUR 28889 EN, Publications Office of the European Union, Luxembourg,; ISBN 978-92-79-76842-2; doi:10.2760/953261; JRC109246

Tauson, M. \& Stannard, L. (2018) 'EdTech for learning in emergencies and displaced settings: A rigorous review and narrative synthesis'. London: Save The Children https://resourcecentre.savethechildren.net/node/13238/pdf/edtech-learning.pdf

Etsuko Toyoda (2016) Intercultural knowledge, awareness and skills observed in a foreign language classroom, Intercultural Education, 27:6, 505-516, DOI: $10.1080 / 14675986.2016 .1256600$

World Bank. (2016) ICT and the Education of Refugees: A Stocktaking of Innovative Approaches in the MENA Region. World Bank, Washington, DC. (C) World Bank. https://openknowledge.worldbank.org/handle/10986/25172 License: CC BY 3.0 IGO." 